\title{
TECHNOLOGY-BASED TEACHING STRATEGIES IMPLEMENTED BY ENGLISH TEACHERS BEFORE AND DURING COUID-19 IN EFL CONTEXT
}

\author{
Aminah \\ Institut Parahikma Indonesia \\ aminah.faerob@parahikma.ac.id \\ Nurwahida \\ Institut Parahikma Indonesia \\ nurwahida.yusuf@parahikma.ac.id \\ Nurmawati \\ Institut Parahikma Indonesia \\ nurmanurmawati899@gmail.com
}

\begin{abstract}
This study aimed at finding out the technology-based teaching strategies implemented by English teachers in teaching English before and during COVID-19. This study applied a qualitative design with a case study approach. The participants were two English teachers of SMP Negeri 3 Galesong Utara. The data were collected by using interview and documentation, and they were analyzed by using Miles and Huberman's theory consisting of three steps: data reduction, data display, and conclusion/ verifying. Furthermore, it was revealed from the study that before COVID-19, the teachers applied discovery learning, inquiry strategy, problem-based learning teaching, contextual teaching strategies and interactive teaching in which they applied some technologies such as Internet, wireless speaker Bluetooth, PPT, and LCD in offline class. Meanwhile during COVID-19, the teachers implemented the lecture model through virtual classes, and monitored students and videos of discussions related to the material through WhatsApp, video conference, and by using self-made videos in which the teachers used technologies such as internet, smartphones, laptops, Zoom, Google Classroom, WhatsApp, Online Dictionary, and YouTube. The inhibited factors encountered by teachers before COVID-19 were intake or the reasoning ability, students thinking power which were still lacking, and extended time space for English lessons in class. While during COVID-19, the subdued factor was that students have difficulty in focusing and concentrating during teaching process, difficulty in accessing applications, smartphones and laptops that suddenly went error due to unstable signals. It is suggested that technology-based teaching strategies applied by the teachers should be adjusted with the conditions of the students, and it is pivotal to strengthen teachers' mastery in technology to attract the students in ELT process.
\end{abstract}

Keywords: Technology, Teaching Strategies, EFL Context, Before and During COVID-19

\section{INTRODUCTION}

$\mathrm{I}$

$n$ this era of globalization, the use of technology is growing rapidly, requiring the world of education to make positive innovations for the advancement of education. One of the functions of technology in education is to change conventional teaching into non-conventional. Moreover, since the end of 2019, the world has been shaken by COVID-19. Due to the pandemic, education systems in Indonesia do not work properly. Therefore, it requires the president of the Republic of 
Indonesia issued a policy to temporarily close the teaching and learning process at the school and university level and encourage all to learn from home through online learning or technology in order to break the increasingly troubling viral chain. Referring to the government policy, all of the teachers are required to provide a strong response related to technology-based teaching and must have good technological tools to support teaching activities. It is certainly challenges for teachers, because they have to think harder to understand students in the teaching process during the pandemic, especially English teachers.

In Indonesian context, English is a foreign language that must be studied by students and considering that English is an international language used by all countries. English has a pivotal role as a global language for communication among parlances, and also the effort towards an international standard for the language (Handayani, 2019, p.6). According to Harmer (2007), one of the most broadly used languages in the world is English. It is beneficial for communication between native speakers and non-native speakers of English.

However, teaching English is not always easy in many ways. According to one of present researchers' own experience, students sometimes find English difficult to comprehend and to master. As a result, when learning it, students commonly complain about being weary of learning English. To overcome issues in teaching English, teachers must adopt a non-monotonous teaching strategy and pay more attention to the unique strategies for teaching English. Junior High School is one of the secondary education levels in which the students must learn English that is commonly quite brain draining for them. Therefore, strategies for teaching need to be considered, so the students can understand English in EFL context easily.

As noted by Susanti and Ambiyar (2018) that strategies or techniques in teaching are needed by an educator. The integration of the media is required to improve the quality of education (Dharmayanti \& Oktarika, 2019). Especially the utilization of technology-based media is also indispensable in order to complete the conventional way (Kim \& Whang., 2013). The use of technology-based teaching media in face-to-face or indirect activities can help the interaction process between teachers and students. In this case, Ampa, et al (2013) stated that the computer is one of the technology-based media capable of replacing, or combining graphic/visual media and audio media in the form of multimedia.

Teaching English is not easy. With different levels of skill in each class, teacher must use effective strategies that allow students to learn the material. Teacher must be creative in choosing materials and be able to encourage student interest. Therefore, the teacher needs to control several strategies to maintain the teaching and learning process. Strategies can make learning easier, slightly faster, more pleasant, self-directed, more effective, and adaptable to different conditions.

Teacher should have a strategy in teaching English. The strategy mostly involves setting goals, determining actions to achieve goals of teaching. A strategy can be planned or established as a pattern of action as an organization adjusts to its surroundings. Nevertheless, according to Armstrong (2020), teaching strategies are ways used to help students acquire the essential course content and set future 
goals that are attainable. Teaching strategies identify the many accessible learning techniques so that they may build the best approach for dealing with the selected target group.

Technology-based teaching is still considered as a new breakthrough in teaching and learning activities in which the process of teaching and learning activities between students and teachers do not need to be present in classroom. Technology also can be defined as a media facilitating students to understand the material well as confirmed by Ajayi (2009) who explained that ICT may be described as a technical instrument for transmitting (outputting/transferring) information. They rely only on internet connection and supporting applications such as WhatsApp, Google Meet, and Zoom and technological equipment to do the teaching process. The process can be done from a distant place even in the offline class. Because of the ease and practicality of virtual learning systems or online learning, it is not surprising that many educational units use online learning systems. Thus, technology-based teaching can be done from anywhere and anytime in accordance with the agreement that has been determined between teachers and students, students can also develop knowledge gained from their teachers by searching for information through the internet related to materials taught by teachers (Adijaya \& Santosa, 2018).

From the initial research, teachers need to be equipped with strategies in teaching English. Thus, the researchers decided to do a study at SMP Negeri 3 Galesong Utara because it was worth it. Referring the described background, the review of related literatures is elaborated below.

\section{REVIEW OF LITERATURE}

\section{Teaching Strategies}

According to Indah (2011), in her research about teachers' strategy in teaching English Speaking at the Second Grade of SMPN 2 Pare indicated that the teacher used four techniques in teaching English speaking, those are discussion, debate, role playing, and daily conversation. In this case, the research found some strategies of English teacher more effective in teaching English speaking to students of the second grade in SMPN 2 Pare. She discovered that role-playing is the best way of teaching English since student practice is generally done directly in school.

Another research related to topic discussed teachers' strategy in teaching English to overcome students' errors in pronunciation at MA Nurul Jadid Paiton Probolinggo conducted by Badriyah (2016). It was found out how the teachers overcome students' errors in pronunciation by using coaching. Coaching involves the teacher saying a words or structure, and getting the students to repeat it. Drilling is an excellent method for overcoming learners' pronunciation mistakes and increasing their ability to speak words.

Furthermore, Apriyandini (2016) had discussed about an analysis of English teaching strategies at Vocational High School of Art (a Case Study at SMK Negeri 8/SMKI Surakarta in Academic Year 2015/2016) which aimed to investigate the teaching strategies, and to describe the implementation of teaching strategies at the classroom practice. Based on the result of the research, it was presented that 
teachers employ six different techniques such as teaching document strategies, questioning strategies, utilizing students' linguistic knowledge, personalized help, motivating strategies, and evaluation strategies are among them.

The other research was also done by Wahidah (2016) who investigated about teachers' strategies in teaching English at Muslim Witaya Phuket School. As a consequence, she revealed four types of teaching strategies often employed by English instructors at Muslim Wittaya Phuket namely direct teaching, mastery learning, cooperative learning, and problem-based learning.

Another study was carried out by Lestiyanawati (2020) who discussed about strategies and problems faced by Indonesian teachers in conducting E-learning system during COVID-19 outbreak. The purpose of this study was to find out and describe the strategies applied and also the problems faced by teachers in doing E-learning during the COVID-19. The findings showed that there were three teaching strategies applied by teachers, they were: applying online chat, used video conference, and combining both online chat and video conference in online teaching and learning process. Some of the problems also arose during e-learning, a total of 6 problems. The arisen teaching problems were: the teachers' disability in accessing technology, school facilities in supporting e-learning, andthe difficulties in explaining the material, students' limitation in accessing the internet, students' economically disadvantaged family background, and parents' support system.

Furthermore, The European Commission (2001) shows that technology provides good benefits for students and some applications that have the function of facilitating lecturers in the teaching and learning process as well as students in receiving lessons and sending assignments. However, in using some of these applications, one of which is the use of the Google Meet application which cause some problems faced by students, when the lecturer conducts web courses are used for online learning in the teaching and learning process. The next application utilization is Google Classroom which is functioned as a place for sending tasks and attendance.

Aflah (2019) has conducted research aimed at explaining the nature of technology integration and its use in language classes along with multimedia Technology-based frameworks in a library review process. The results of this study cover activities that can be used by teachers or instructors during the teaching process in language classes. This study also explains some previous research that also discussed the use of multimedia technology to improve students' English language skills. In contrast, Ghavifekr and Rosdy (2015) had discussed about teachers' perceptions on integration of ICT to support the teaching and learning process in the classroom. The results of this study showed that technologybased teaching and learning are more effective compared to traditional classes.

There are many philosophers of education who have defined teaching including Hirst in Smith (2018) who argued that when it comes to teaching it should include two things. The first one must start with real intent, and the second must teach taking into account one's feelings, needs, and expectations which it can only be said that teaching is one acquires something from what has been attentive of 
teaching. The technology-based teaching and learning is more effective compared to traditional classroom.

\section{Technology that supports teaching}

Here are some information and technology products that can be utilized in supporting technologybased teaching:

1. Cetinkaya (2017) defines that WhatsApp as a Modern technology is effective in increasing success in learning to develop students' positive opinions towards the use of WhatsApp in learning. Besides, Amry (2014) argues that WhatsApp is also a tool used to increase students' motivation and interest in learning.

2. Google Classroom is an app designed to help students and teachers communicate in a virtual classroom. As Azhar \& Iqbal (2018) said that by using Google Classroom, teachers can manage classroom activities effectively and efficiently.

3. Google Meet is a communication service developed by Google that serves to make it easier for people who want to pawn meetings virtually.

4. Zoom cloud meeting was a software program of exclusive video teleconferencing developed by communication video zoom.

5. According to Almurashi (2016), who explained that YouTube is Social media networks are also utilized in the teaching and learning process.

Many other applications can be applied as modern tools and technologies that can be utilized to support teaching in the good class during pandemics. However, the decision in choosing the right set of technologies or applications must be chosen deliberately, based on the teacher's ability to access technology, student conditions, and other support systems.

\section{Principles of Effective Teaching Strategy}

According to Devlin and Samarawickrema in Saputra and Aziz (2020), there are nine principles of effective teaching strategy that are teaching and curriculum design requires to be noted on gathering students" future needs, involving the improvement in students of generic capabilities which are critical thinking, teamwork and communication skills, and the students have to have a comprehensive understanding of fundamental concepts. The significance of what is taught has to be recognized by implementing real-life, local examples, and by connecting theory to practice, student beliefs have to be trained to deal with misconceptions. In addition, teachers should give motivation to students through presenting their own enthusiasm, encouraging students and delivering interesting, enjoyable and active classes. The curriculum design should confirm that aims, concepts, learning activities and assessment, and every lesson must be carefully planned but flexible so that essential adaptations may be created based on feedback during the class. Eventually, the assessment must be regular with the preferred learning outcomes. Therefore, it will be authentic tasks for the discipline or profession. 


\section{Variety of Teaching Strategy Activities}

Variety of teaching strategies are described by Cox (2015) as follows:

1. Teaching Strategy - Expository Strategy

Direct instruction is what an expository strategy is all about. Students take notes while a teacher lectures in the front of the room. When students learn on their own they may become sidetracked and confused by irrelevant materials, making it harder to determine what is significant.

a) The Lecture Method.

The lecture is a teaching method that entails orally illuminating learning materials for a group of listeners in order to achieve specific learning objectives in a relatively short period of time. This is consistent with the definition and goals of the Expository Method, which is a lecture or one-way strategy.

\section{b) Method of Demonstration}

Demonstration method is a method of presenting lesson, material to students by demonstrating a specific process, situation, or object being studied, whether actual or imitated by speech. Thus, the teacher demonstrates what is being learned by these students.

c) The Socio Drama Method

Socio drama is still a type of drama that dramatizes conduct in connection with social issues. As a result, in the classroom, the instructor explains the behavior by dramatizing it in order to set an example for the students.

\section{Teaching Strategy - Inquiry Strategy}

The teaching of scientific inquiry as content by providing a context for the teaching and learning of scientific processes is known as inquiry as a teaching strategy. The teaching inquiry strategy is a set of learning activities that emphasize critical thinking and analytical skill in order for students to come up with their own solution to the problem.

There are several things that become the main strategy of inquiry strategy including how to emphasize maximum student activity in searching and finding, implying that the inquiry strategy makes students the object of learning. If the lesson material to be given is not in a full shape or notion, but rather a conclusion that needs to be proven. The other requirements are if the learning process is not based on the students' interest in a subject, and if the teacher teaches a set of students who, on average, have the desire and ability to think, this method will be less effective when applied to students who do not have this skill. Besides, the teacher can maintain control, if there are not too many kids learning or if there is enough time for the teacher to employ a student-centered approach. Thus, an inquiry strategy is one that emphasizes children's intellectual growth.

\section{Teaching Strategy - Contextual Teaching and Learning Strategy}

Contextual teaching and learning (CTL) entails integrating learning into the actual world to make it more meaningful for the students. Contextual teaching and learning has its own characteristics such as learning is done in an authentic context (meaningful learning); it is done by providing meaningful 
experiences to students (learning by doing) through group work, discussion, mutual correction between friends (learning in group); it provides an opportunity to create a sense of togetherness, working together, and understanding each other in depth (learning to know each other deeply) and it is carried out actively, creatively, productively, and attaches importance to cooperation (learning to inquiry, and to work together); it also takes place in a fun environment (learning to ask for an enjoyable activity).

4. Teaching Strategy Problem Based Instruction

Problem-based teaching another teaching strategy that challenges students to seek solutions to real-world problems. Problem-based teaching generally composed of two parts: a question or a problem, which is either student or teacher generated, and the students' arrival at a solution.

In addition, there are several components of the teaching strategy (Hamruni, 2011: 22). Firstly, teacher who has a role to create the students' environment in order to suit with the expected environment from the students' learning process that finally students can get the expected learning outcomes. The second component is students who are the component who doing the learning activity to develop the real potential competence to achieve the learning objectives. The third part is the objectives which become the basic foundation to determine the strategy, learning material, media, and the evaluation of learning. Another pivotal component is learning material which is a medium to achieve goals, in the form of learning material which is arranged systematically and dynamically in accordance with the direction and development progress of science and the demands of society.

In order to make the learning objectives can be achieved optimally, so determining the learning strategies need to be formulated as the components of learning activities in accordance with the standards learning process. Method of teaching is urgent as the way used to achieve the learning objectives which has been planned combined with media of learning consisting of tools used in learning are anything that can be used to achieve the learning objectives.

Furthermore, the other crucial components are source of learning, evaluation, and environment. Source of learning is everything that can be used as a place or reference where learning materials can be obtained while evaluation is a component that functions to determine whether the goals set have been reached or not. Similarly, the environment will influence the teacher in determining teaching learning strategies.

\section{METHOD}

\section{Participants}

This study was conducted at SMP Negeri 3 Galesong Utara which is the only junior high school in Bontosunggu village. The school is situated at Jl. Poros Galesong Utara No.1, Bontosunggu, Galesong Utara, Takalar, South Sulawesi with B accreditation status. In this study, the researchers had used purposive sampling technique to determine participants. The researcher had investigated two English teachers because they met the researchers' requirements, which include teaching English in an 
EFL environment, adopting teaching techniques prior to COVID-19, and integrating technology while teaching English before and during COVID-19.

\section{Research Design}

This research was focused on exploring the technology-based teaching strategies of EFL teachers at SMPN Galesong Utara. Qualitative research is research that produces descriptive data such as written or oral words from people and observed behaviors (Saat and Mania, 2019). This research used a case study design that aims to explore technology-based teaching strategies before and during COVID-19 applied by EFL teachers at SMPN 3 Galesong utara, and focused only on one selected phenomenon and wants to be understood in depth by ignoring other phenomena by using interviews and documentation to gather information from participants while recording to maintain the authenticity of the data obtained.

\section{Instruments and Procedures}

To answer the research questions, the researchers conducted an in-depth interview (open-ended questions) and documentation. The researchers used semi-structured interview in the study, with a series of basic questions that can then be modified in line with the interview process. The characteristics of the interview model used a one-on-one interview, a richly communicative exchange mode in which the gestural aspects of the discourse are seen by the participants. The researcher also used documentation as a method of data collection in this study and to find out the sitcresuation of objects for this study.

\section{Data Analysis}

In analyzing the data, the findings of data collection were analyzed with thematic analysis by using Miles and Huberman (2020) theory consisting of three steps: data reduction, data display, and conclusion/ verifying. The data result from the interview with participants were transcribed and then labeled as the data themes.

\section{FINDINGS AND DISCUSSION}

\section{Findings}

\section{Technology-based Teaching strategies applied by English teachers in teaching English before} COVID-19

From the data collected, it was revealed that in implementing teaching strategies, Teacher 1 (T1) and teacher 2 (T2) had some different perspectives related to following items: preferred teaching strategies, technology used in teaching process and supporting factors.

\section{Preferred teaching strategies}

In applying teaching strategies, the teachers tend to choose the preferred teaching strategies based on the circumstances, situations and student's needs. One teacher (T1) clearly commented that "the strategy depends on the circumstances, situations and students' needs. In this case, I use discovery learning teaching strategies." It can be inferred that the first participant preferred discovery learning strategies based on the students' circumstances, situations, and students' needs. The reasons of applying that strategy were quite effective especially for the students whose intake is still relatively lacking. In 
addition, it is the first step of stimulation. However, another perspective had been revealed by the second participant (T2) who stated that before the pandemic, she implemented contextual teaching strategies, and used more interactive media such as word wall media. Therefore, the researchers assume that before the pandemic, English teachers implemented different teaching strategies adapted to the student's circumstances during the teaching process.

\section{Technology used in teaching process}

In term of technology used in the teaching process before covid 19 , the researchers found that the teachers used several technological frameworks, namely the internet, Internet, wireless speaker Bluetooth, Power Point, and LCD and other technological equipment. One participant mentioned that before pandemic, she usually used the help of the internet, wireless Bluetooth speakers and LCD as the school provided them with projector. In line with the second participant who also mentioned that in her teaching before covid 19 , the use of speaker to play the simple conversation in teaching dialogue related to daily activities was also used although it was not as frequents as of during the COVID-19. It can be concluded that both of the teachers using technology when implementing English teaching strategies before the COVID-19 pandemic.

\section{Supporting factors}

The participants reported that there were several supporting factors that made the teaching strategies they implemented before the pandemic effective, including teachers being able to interact directly and be able to better master the classroom. One participant said that she was able to interact directly with students, mastering the class so that I could immediately know the problems, obstacles of students during the teaching and learning process". She also added that the students could concentrate more in face-to-face classroom. She illustrated when one student got difficulties in comprehending the materials, the teacher could just review the materials and others could listen so the lesson could be as the reinforcement for the whole class.

Meanwhile, the second teacher added that before covid 19, the use of media such as word wall made the students more interested in learning vocabulary and felt more challenged to be able to know more than their friends. Based on this data, the researchers can conclude that with face-to-face teaching directly in class with students, teachers can better master the classroom. In addition, the student motivation is also higher in these case students are more enthusiastic.

\section{Technology-based teaching strategies implemented by English teachers during COVID-19}

The findings about technology-based teaching strategies implemented by English teachers during COVID-19 are related to the following items: technology used by the teachers, the benefits of technology, preferred teaching strategies, preferred applications.

\section{Technology used by the teachers}

Based on the results of the interview, the participants said that during the pandemic, they used technology especially as it had been instructed by the school unless the teaching process was stopped. One teacher stated that "During the pandemic, I used technology to support my teaching materials such 
as online dictionary and utilized a laptop and mobile phone to find various information related to materials that I would teach in class. During the pandemic, both teachers used laptop and mobile phone more frequently to suppOort their teaching.

\section{The benefits of technology}

Based on the result of the interview, the researchers found various benefits of the use of technology by the participants specially to support their teaching. The first participant reported that technology will make life easier not only in the world of education. She said that "teachers and students would be greatly helped if they use technology. For example, the current dictionary is certainly needed in teaching foreign languages." The second participant also stated that the use of technology makes her teaching become more interesting.

\section{Preferred teaching strategies}

Participants reported that during the pandemic, the teaching process was severely hampered because teachers could not implement their teaching strategies to the fullest. The participants confessed that they could no longer use one strategy yet more varied. The first participant said that she used various strategies in her teaching during Covid 19. She added "I find it very difficult to implement one of the four teaching strategies, whether it is discovery learning which has 6 syntax inquiry learning that has five syntax problem-based learning that has 5 syntax or project-based learning that has 6 syntax." For this participant, teaching through WhatsApp is limited to apply those syntaxes. Therefore, she only tells basic competencies and learning goals, gives short materials, and then asks students if there is something less understood. She also sometimes sent them videos related to the materials she delivered. This is in line with the second participant who said that she used a lot of videos and turned the teaching into the project-based learning. She used them to make the students understand the material better.

Based on the above explanation, the researchers can conclude that the strategies used in the learning process were using online media, and in implementing the strategy, teachers used a two-way system namely controlling students and assigning tasks.

\section{Preferred Applications}

Based on interviews, the researcher obtained information related to the applications that teachers used during the pandemic to help them in the teaching process. The two participants used WhatsApp and other applications such as Google Classroom, and zoom meeting. The first participant said that "you can only use WhatsApp because many students come from lower middle economic class". According to her, using Zoom application is too expensive. She also used google classroom but only for some time. Unlike the first participant, the second participant combined all the applications in her teaching. She said "I use WhatsApp, Google Classroom and Zoom meeting apps."

\section{Effects without using technology}

Based on research interviews, researcher found an interesting fact which is how important technology is for teachers in this day and age. Technology has been very influential in the continuity of the learning process. It is evidenced by the result of interview. According to the first participant's 
perspective, she would have a little trouble teaching without the help of technology. She said "it is quite difficult for teachers to be able to present varied lessons without being supported by technology." However, different opinion was also put forward by T2, that is "the teacher should use an interesting handout, the medium of surrounding materials that easy to obtain and use more games in the classroom so that they are more interested even without the presence of technology."

The inhibited factors of applying those technology-based teaching strategies before and during COVID-19

The inhibited factors before COVID-19 found in the interview were the lack of students' intake which refers to the students' understanding about the material. While another teacher thought that her inhibited factor was the lack of time in explaining lesson. The first participant said that "Discovery learning will have 6 syntax namely stimulation, problem statement, data collection, data processing, verification and generalization. Here I am usually constrained in the third syntax maybe because the intake of students is still lacking." While the second participant stated that the inhibited factor, she experienced was the extended time space for English lesson in class.

\section{Discussion}

\section{Technology-based Teaching strategies applied by English teachers in teaching English before COVID-19}

The findings of this research, in term of preferred teaching strategies the researcher found that before the pandemic, English teachers implemented different teaching strategies during the teaching process. The first teacher (T1) preferred discovery learning the more dominant, inquiry learning and problem-based learning strategies based on the students' circumstances, situations, and students' needs. It is line with the findings by Wahidah (2016) that revealed that problem-based learning is one of the teaching strategies that the choices of teachers.

Compared to the findings of the interview with the second teacher (T2), the T1 applied contextual teaching strategy. Teacher used authentic teaching media and engages students to be more active during the learning process. This will certainly make students get a fun learning experience and have its own meaning. Based on explanation, there are similarities of the theories from chapter two, the theories by Cox (2015) who stated that teaching contextually require the integration of learning into the real world to make it more meaningful to students as well as incorporating students' unique abilities, interests, and experiences into what and how they learn.

In term of technology used in teaching process, the researcher found findings of this study related to the technology used by participants in the teaching process before the COVID-19 pandemic. Teachers used several technological frameworks, namely the internet, Internet wireless speaker Bluetooth, Power Point, and LCD and other technological equipment. It is in line with Ajayi (2009), explained that information and communication technology (ICT) may be described as a technical instrument for collecting (inputting/gathering), compiling (processing/analyzing), and transmitting (outputting/transferring) information. 
$206 \mid \begin{aligned} & \text { Elstic-IJ Vol. } 1 \text { No. } 3 \text { (2021) } \\ & \text { Aminah, Nurwahida, Nurmawati: Technology-Based Teaching... }\end{aligned}$

Regarding supporting factors, there were several supporting factors that made the teaching strategies they implemented before the pandemic effective, including teachers being able to interact directly and be able to better master the classroom. In addition, learning motivation and student enthusiasm are also it is one of the supporting factors.

\section{Technology-based teaching strategies implemented by English teachers during COVID-19}

In term of technology used by the teacher, researcher found that all teachers used technology while teaching during the COVID-19 pandemic, and the use of the technology was even more commonly used than before the pandemic. Meanwhile, the preferred teaching strategies, based on the interview, researcher obtained information in which teachers applied strategies that are different from the strategies applied in the time before the COVID-19, During the pandemic the teachers only explained a little, then students are required to be more active in searching, teachers only provided introductions and images related to the material they teach, as well as help from teachers, namely teachers send videos related to teaching materials then students can ask what is less understood through chat via WhatsApp messages and sometimes used video conference. It is supported by Lestiyanawati (2020) who suggested that teaching strategies implemented by teachers, namely: implementing online chat, using video conferencing, and combining online chat and video conferencing in the online teaching and learning process.

Furthermore, in term of preferred applications, the researcher obtained information related to the applications that teachers used during the pandemic to help them in the teaching process. All teachers take advantage of the Zoom and Google Classroom apps to replace face-to-face classes with virtual classes, but to provide additional explanations teachers prefer to use the WhatsApp app to make it easier for them to communicate with students through class groups that have been created. It is related to the technology supports in teaching which Cetinkaya (2017) defines about WhatsApp as a Modern technology which is effective in increasing success in teaching and learning to develop students' positive opinions towards the use of it in learning process.

Besides, the effect without using technology that the researchers found was how important technology is for teachers in this age in which it has a very influential role in the continuity of the learning process. It is in line with what Adijaya and Santosa, (2018) explained that technology-based teaching can be done from anywhere and anytime in accordance with the agreement that has been determined between teachers and students. Students can also develop knowledge gained from their teachers by searching for information through the internet related to materials taught by teachers.

\section{The inhibited factors of applying technology-based teaching strategies}

In term of inhibited factors, the researcher found in the interview was the lack of students' intake which refers to the students' understanding about the material. While another teacher thought that her inhibited factor was the lack of time in explaining lesson. These findings are line with Lestiyanawati (2020), the arisen teaching problems were: the teachers' disability in accessing technology, school 
facilities in supporting e-learning, and the difficulties in explaining the material, students' limitation in accessing the internet.

Moreover, in the part of the challenges faced by students, researcher also found some faced by students throughout the technology-based teaching applied by teachers since COVID-19. In this case, among them are network problems and supporting technology used during the teaching and learning process. It is supported by Lestiyanawati (2020) who stated that the challenges of technology-based teaching strategies are students' limitationin accessing the internet, students' economically disadvantaged family background, and parents' support system. Besides, the technical issues encountered by the teachers, based on their experience which was technology problems when teaching English during the COVID-19 pandemic such as mobile phones and laptops that suddenly went error as well as unstable signals or the poor network.

From the discussion above, the researchers suggested that technology-based teaching strategies applied by the teachers should be adjusted with the conditions of the students and existing facilities/ technologies in that institution.

\section{CONCLUSION}

Technology-based teaching strategies applied by English teachers in teaching English before COVID-19 were discovery learning, inquiry learning strategy, problem based learning teaching, contextual teaching strategies and interactive teaching. Meanwhile, the technology used including Internet, wireless speaker Bluetooth, PPT, and LCD which means that the technology is described as media to transfer information to the students in offline class in order to make them understand the materials easily.

In addition, technology-based teaching strategies implemented by English teachers during COVID19 were the lecture model. Regarding the procedure, it was conducted through virtual classes. Then, the teacher monitored students through videos of discussions related to the material which was sent to WhatsApp, using video conference, and using self-made videos which was then uploaded in YouTube. In this case, the teachers prepared teaching based on multimedia technology. Based on the findings, the participants used several applications such as: WhatsApp, Google Classroom, and Zoom while teaching during COVID-19.

Moreover, the inhibited factors before COVID-19 were intake or the reasoning, ability and students thinking power which still lacking and extended time space for English lessons in class. Whereas, during COVID-19, the inhibited factors were Students have difficulty are focusing and concentrating during teaching process, difficulty accessing apps like Zoom and Google Classroom, smartphones and laptops that suddenly went into error as well as unstable signals or the poor network.

\section{REFERENCES}

Adijaya, N., \& Santosa, L. P. (2018). Persepsi Mahasiswa dalam Pembelajaran Online. Wanastra Jurnal, 10(2), 105-110. https://doi.org/2579-3438 
Aflah, M. N. (2019). Integrating Technology in Basic English Class. ETERNAL (English, Teaching, Learning, and Research Journal), 5(2), 195-202.

Ajayi, L. (2009). An exploration of pre-service teachers' perceptions of learning to teach while using asynchronous discussion board. Journal of Educational Technology \& Society, 12(2), 86-100.

Ally, M. (2008). Foundations of Educational Theory of Online Learning. In Anderson, T. (Ed.) The Theory and Practice of Online Learning. (pp. 15-44). Athabasca University, Canada: Alberta.

Almurashi, W.A. (2016). The Effective Use of Youtube Videos for Teaching English Language in Classroom as Supplementary Materials at Taibah University in Alula. International Journal of English Language and Linguistics Research. 4(3), 32- 47.

Ampa, A. T., Rasyid, M. A., Rahman, M. A., Haryanto, Basri, M. (2013). The Implementation of Multimedia Learning Materials in Teaching English Speaking Skills. International Journal of English Language Education, 1(3): 293-304. doi: 10.5296/ijele.v1i3.4153

Amry, A.B. 2014. The Impact of WhatsApp Mobile Social Learning on the Achievement and Attitudes of Female Students Compared with Face to Face Learning in the Classroom. European Scientific Journal, 10(2)

Apriyandini, D. (2016). An analysis of English teaching strategies at vocational high school of art (Master's thesis). Retrived from https://eprints.uns.ac.id

Armstrong, S. (2020). Article for Innovate My School: The 10 most important teaching strategies. Retrieved from http://www.innovatemyschool.com/ideas/the-10-mostpowerful-teaching-strategies/

Azhar, K.A \& Iqbal, N. (2018). Effectiveness of Google Classroom: Teachers Perception. Prizren Social Science Journal, 2(2), 1-16.

Badriyah, N. (2016). Teachers' strategy in teaching English to overcoflahme students' errors in pronunciation at MA Nurul Jadid Paiton Probolinggo. (Publish thesis, University of Nurul Jadid)

Carliner, S. (1999). Overview of online learning. Amhers, MA: Human Resource Development Press.

Cetinkaya, L. (2017). The Impact of Whatsapp Use in Success of Education Process. International Review of Research in Open and Distance Learning 18(7).

Cox, J. (2015). Five essential teaching strategies to deliver an effective lesson. Retrieved from https:// www.teachhub.com/teaching strategies/2015/

Dharmayanti, W. \& Oktarika, D. (2019). Pengembangan Media Pembelajaran Berbasis Multimedia Interaktif untuk Guru IPA die Sekolah Menengah Pertama. Jurnal Pendidikan Informatika dan Sains, 8(1): 41-51. Retrieved from http://www.journal.ikippgriptk.ac.id

European Commision (2001). The E- Learning Action Plan: Designing tomorrow's education. Retrieved from http://www.elearningeuropa.info.

Ghavifekr, S., \& Rosdy, W. A.W. (2015). Teaching and learning with technology: Effectiveness of ICT integration in schools. International Journal of Research in Education and Science, 1(2), 175191. Retrieved from https://files.eric.ed.gov/fulltext/EJ1105224

Handayani, F. (2019). Investigating teachers' strategies in teaching English (A case study of two outstanding English Language Teacher at SMAN 1 Badegan and SMAN 1 Ponorogo), (Publish thesis, Universitas Muhammadiyah Ponorogo)

Hamruni, A. (2011). Strategi Pembelajaran. Yogyakarta: Insan Madani. 
Harmer, J. (2007). How to teach English. Harlow: Pearson Education Limited.

Indah, M. (2011). Teacher's strategy in teaching English speaking at second grade of SMPN 2 Pare Kediri (Publish thesis, IAIN Sunan Ampel Surabaya).

Khan, B. (1997). Web-based instruction: What is it and why is it? In B. H. Khan (Ed.), Web-based instruction (pp. 5-18). Englewood Cliffs, NJ: Educational Technology Publications.

Kim, D. J., \& Whang, W. H. (2013). Cognitive Synergy in Multimedia Learning. International Education Studies, 6(4): 76-84.

Lestiyanawati, R. (2020). The Strategies and Problems Faced by Indonesian Teachers in Conducting Elearning during COVID-19 Outbreak. CLLiENT (Culture, Literature, Linguistics, and English Teaching), 2(1), 71-82.

Miles, M. B., Huberman, A. M., \& Saldana, J. (2020). Qualitative Data Analysis: A methods sourcebook. United Kingdom: SAGE Publications.

Naidu, S. (2006). Online Learning: a guidebook of principles, procedures and practices, New Delhi: Aishi Creative Workshop.

Perron, Taylor, Glass, Margerum-Leys. (2010); Information and Communication Technologies in Social Work, 11(1), 67-81. Retrieved from https://www.academia.edu/31091653

Ring, G. \& Mathieux, G. (2002). The key components of quality learning. Paper presented at the ASTD Techknowledge Conference, Las Vegas.

Rossett, A. (2002). Waking in the night and thinking about e-learning. In A Rossett (Ed.), The ASTD e-learning handbook (pp. 3-18). New York: McGraw-Hill.

Saat, S. \& Mania, S. (2019). Pengantar Metodologi Penelitian: Panduan Bagi Peneliti Muda. Gowa: Pusaka Almaida.

Saputra, A. Aziz. (2020). An Analysis of Using Participation Point System To Teach Structure 4 At The Fourth Semester Students In English Education Department Of State Institute for Islamic Studies (Iain Salatiga). State Institute for Islamic Studies of Salatiga.

Selvan, T., Sivakumar, Sevukan,R., (2012), Information and Communication Technology, IJLIS (International Journal of Library and Information Science 1(1), 15-28. Retrieved from www.iaeme.com/ijlis.html.

Smith, M. K. (2018). 'What is teaching?' in the encyclopedia of pedagogy and informal education. Retrieved from https://infed.org/mobi/what-is-teaching/

Susanti, W. \& Ambiyar. (2018). Analisis Korespondensi Hubungan Strategi Pembelajaran dengan Hasil Belajar Mahasiswa. Seminastika, 1(2): 209- 213.

Wahidah, F. I. (2016). Teachers' Strategies in Teaching English at Muslim Wittaya Phuket School. (Publish thesis, IAIN Tulungagung) 